\title{
CORRUPTION, CRIME VICTIMIZATION AND COMMUNITY PARTICIPATION IN LATIN AMERICA
}

CORRUPCIÓN, VICTIMIZACIÓN POR DELITO E PARTICIPACIÓN COMUNITARIA EN

AMÉRICA LATINA

CORRUPÇÃO, VITIMIZAÇÃO POR CRIME E PARTICIPAÇÃO COMUNITÁRIA NA AMÉRICA

LATINA

\author{
Alejandra Armesto ${ }^{1}$ \\ Facultad Latinoamericana de Ciencias Sociales, Cidade do México, México
}

\begin{abstract}
Studies about the effects of victimization on social capital find support for contradictory hypotheses: crime victimization leads to both social withdrawal and greater participation. Under what conditions does crime victimization induce community participation? This article argues that this relationship is conditional on government corruption. I test this claim with national survey data collected in 18 countries as part of the AmericasBarometer 2012 study. Using hierarchical linear regression analyses, the study shows that victims of crime participate in community organizations at a higher rate than non-victims, and that this participation is even higher in countries with high levels of government corruption.
\end{abstract}

Keywords: corruption; crime victimization; participation; Latin America.

Resumen: Los estudios sobre la relación entre victimización delictiva y capital social sostienen hipótesis contradictorias: la victimización por delito induce aislamiento social y mayor participación. ¿Bajo qué condiciones la victimización propicia la participación comunitaria? Este artículo argumenta que esta relación está condicionada por la corrupción gubernamental. Esta hipótesis es puesta a prueba con datos de encuestas nacionales recogidos en 2012 en 18 países de América Latina por el Barómetro de las Américas. Los análisis jerárquicos lineales muestran que las víctimas participan en organizaciones comunitarias más que quienes no han sido víctimas y que dicha participación es mayor en países más corruptos.

Palabras clave: corrupción; victimización por delito; participación; América Latina.

Resumo: Estudos sobre a relação entre a vitimização e capital social sustentam hipóteses contraditórias: a vitimização criminal leva ao isolamento social e maior participação. Sob que condições a vitimização pelo crime induz a participação em associações comunitárias? Este artigo argumenta que essa relação é condicionada pela corrupção do governo. Esta hipótese é testada com dados coletados em 2012 em 18 países da América Latina pelo Barômetro das Américas. Usando regressão linear hierárquica, o estudo mostra que as vítimas de crimes participaram em organizações comunitárias em uma taxa maior do que as não-vítimas, e que essa participação é ainda maior em países com altos níveis de corrupção no governo.

\footnotetext{
${ }^{1}$ Profesora investigadora en la sede mexicana de la Facultad Latinoamericana de Ciencias Sociales, donde también coordina el Doctorado en Ciencias Sociales. E-mail: <alejandra.armesto@gmail.com>.
} 
Palavras-chave: corrupção; vitimização por crime; participação; América Latina.

\section{INTRODUCTION}

Studies about the effects of victimization on social capital find support for contradictory hypotheses: crime victimization leads to both social withdrawal and greater social participation and political involvement. On the one hand, victimization has been linked to lower levels of wellbeing, a more limited social life, and lower levels of trust and participation. On the other, psychologists have found that victims of violence are resilient, and political scientists have linked victimization to higher political participation.

Under what conditions does crime victimization encourage community participation? This paper argues that higher community participation in response to crime victimization is contingent on corruption levels; more specifically, higher levels of corruption should intensify the effect of victimization on community participation.

The analysis is based on national survey data collected in 18 Latin American countries as part of the AmericasBarometer study. Latin America offers a good case to study the effects of corruption on the relationship between crime victimization and participation for several reasons. First, the region has become the most violent in the world. According to a United Nations study on criminal violence, in 2012, about 30 percent of the homicides around the world took place in Latin America, while the region's 574 million inhabitants comprise just 8 percent of the global population (UNODC, 2014). Second, while the region has high levels of violence and corruption, there is ample variation in victimization and corruption among Latin-American countries. Last, the focus on countries with similar developmental experiences makes more likely that the type of violence and the understanding of what corruption means will be similar in different countries of the region.

The results are consistent with the hypotheses put forth. Findings indicate that, first, crime victimization is positively related to both predicted outcomes -social withdrawal and participation in community organizations- and second, the effect of crime victimization on withdrawal and participation is moderated by the level of corruption.

The article is organized as follows. First, I discuss the extant theories about the effects of crime victimization on participation and lay out my expectations regarding conditional effects. Next, I introduce the data on which the study bases its claims. The following section develops the 
multilevel model of participation, which accounts for the nested structure of the data. The last section discusses the main results, and the conclusion summarizes the findings and raises questions for future research.

\section{CRIME VICTIMIZATION AND PARTICIPATION: THE INTENSIFYING EFFECTS OF CORRUPTION}

What are the effects of crime victimization on participation? The increasing numbers of studies about the legacies of crime victimization and violence on social capital yield mixed results. Early contributions to this debate argue that victimization hampers the social fabric by inducing victims to seclusion and social withdrawal. More recent studies suggest that exposure to violence -both political and criminal- can encourage collective action, as well as social and political participation. When are victims of crime more inclined to participate than to withdraw? This study claims that participation in community organizations is higher among victims of crime and that this relationship is intensified by government corruption. This requires that we first summarize existing knowledge about the effects of each victimization and corruption on participation. Only then I will discuss why the relationship between victimization and participation might be affected by corruption.

Crime victimization and more generally exposure to violence can have a strong depressant effect on social participation because of the high social, economic, and psychological costs. Victims have been described as less satisfied with life (COHEN, 2008), less trustful (BREHM AND RAHN, 1997), less happy (CHENG AND SMYTH, 2015; POWDTHAVEE, 2005; STAUBLI, KILLIAS, AND FREY, 2014; STICKLEY, KOYANAGI, ROBERTS, GORYAKIN, AND MCKEE, 2015), and more socially withdrawn (DRAKULICH, 2015; MIETHE, 1995). Victims of violent crime withdraw from social activities; they stop participating in community organizations and from attending school (HUGHES, GAINES, AND PRYOR, 2015), they even move out of their neighborhood (DUGA, 1999; SOUTH AND CROWDER, 1997).

On the other hand, recent studies in political science have shown that victimization can have positive impact on political and civic participation. For example, victims of violence in the context of civil war are more engaged in politics (DE LUCA AND VERPOOTEN, 2015). Bellows and Miguel $(2006,2009)$ analyze the effects of civil war in Sierra Leone, and show that 
in regions that had experienced more violence, participation measured in terms of voter registration and group membership was higher. In turn, Blattman (2009) uses data from northern Uganda and links past abduction by rebels and exposure to violence to increased political engagement among victims. Other group-level studies also find heightened social capital, altruism, and political participation in war-affected communities (GILLIGAN, PASQUALE, AND SAMII, 2014; OTO-PERALÍAS, 2015).

There are at least three plausible explanations for participation as a consequence of victimization or exposure to violence: post-traumatic growth, instrumental activism, and social support. The first account draws on psychological research about growth after traumatic experiences. Although psychology has mainly focused on the negative effects of traumatic experiences, more recent studies have reported what has been called "posttraumatic growth" (JAYAWICKREME AND BLACKIE, 2014; TEDESCHI AND CALHOUN, 2004). Traumatic events drive changes of self-perception, life priorities and in relationships. Instrumental activism refers to victims seeking assistance from elected officials or lobbying for policy changes that are related to the crimes they have suffered (BATESON, 2012). The third explanation for higher participation lies in victims' emotional needs. Participation in community and social organizations provides victims with social support that can alleviate the emotional consequences of victimization (BASTIAN, JETTEN, AND FERRIS, 2014; JENNINGS AND ANDERSEN, 1996; JENNINGS, 1999).

Corruption has a negative effect on institutional trust and political participation (ANDERSON AND TVERDOVA, 2003; BANERJEE, 2016; MILES, 2015). Corruption violates universal norms and replaces them with particularistic rules that promote particularized benefits (GRAEFF AND SVENDSEN, 2013). Scandals, massive bureaucracies and public-works projects have led the public to react by losing trust in public officials (BOWLER AND KARP, 2004; CHANG AND CHU, 2006; DELLA PORTA, 2000; INOGUCHI, 2002; SELIGSON, 2002).

Corruption also has a negative effect on generalized interpersonal trust (RICHEY, 2010; ROTHSTEIN AND USLANER, 2005; TAO, YANG, LI, AND LU, 2014). Some institutional arrangements produce standards that reinforce trustworthiness, such as corruption intolerance, contributing to citizens' confidence (PUTNAM, 2000; YOU, 2012). Other arrangements produce just the opposite effects. Where institutions do not treat citizens fairly, they generate citizens who do not trust other individuals and who are less likely to cooperate (HERREROS AND CRIADO, 
2008; ROTHSTEIN AND STOLLE, 2003). For example, in an institutional context of high compliance with the rule of law and low corruption, if someone commits an illegal act against another citizen, ignoring the formal terms of a contract, the transgressor will be punished. If both parties to such a contract know the consequences of violating the contract -and therefore the laws protecting it- they know that breaking the rules does not bring benefits, and they adjust their behavior accordingly. Over time, agents have learned that it is mutually beneficial to respect contracts (GRAEFF AND SVENDSEN, 2013). On the contrary, corruption reinforces particularized trust, trust in members of ones' membership groups. Therefore, in contexts of high government corruption, citizens do not trust outsiders, and trust is bestowed only within tight networks of acquaintances (USLANER, 2008).

In summary, we know that crime victimization encourages participation -in the political, social, and community realms-, second, that corruption reduces trust in political institutions as well as generalized trust; and third, that corruption strengthens trust in members of the in-group. In consequence, we can expect crime victimization to affect community participation depending on the level of corruption. In contexts of high levels of corruption, low institutional trust and low generalized interpersonal trust, victims should have incentives to seek satisfaction to their needs through participation within their networks and less so to be active in the political sphere. Whereas, in contexts of low levels of corruption, the effect of crime victimization on community participation should be milder. The specific hypotheses to be explored in the rest of the paper are the following. First, crime victimization will be positively associated with involvement in community associations. And second, the relationship between crime victimization and participation in community associations will be intensified by the level of corruption.

\section{DATA AND METHODS}

Data for the subsequent empirical analyses are drawn from the 2012 AmericasBarometer. The analyses are based on information from 29,255 respondents in nationally representative surveys fielded in eighteen Latin American countries in 2012. The survey is administered by the Latin American Public Opinion Project (LAPOP) at Vanderbilt University. The LAPOP surveys are representative at the national level for voting-age adults (18 years and older). They are constructed so as to maximize their representativeness with a complex sample design which 
includes stratification and clustering. The sample size for each wave is around 1500 observations and is unweighted with no oversample. ${ }^{2}$ The survey provides information about individuals' victimization, social capital, and socioeconomic background. The data rely on self-reported experiences of victimization, which are less prone to underreporting than official crime statistics. The necessary individual- and country-level variables were available for eighteen Latin American countries: Argentina, Bolivia, Brazil, Chile, Colombia, Costa Rica, Ecuador, El Salvador, Dominican Republic, Guatemala, Honduras, Mexico, Nicaragua, Panamá, Paraguay, Peru, Uruguay, and Venezuela.

\section{DEPENDENT VARIABLE}

The dependent variable is Participation in community organizations, which is measured as an additive index of responses to the following questions:

cp5. "Over the last 12 months, have you helped solve a problem of your community or of the neighbors in your neighborhood?" once a week, once or twice a week, once or twice a year, or never.

Please tell me if you attend meetings of these organizations once a week, once or twice a week, once or twice a year, or never

Cp6. Any religious organization

Cp7. Meetings of a parents' association at school?

cp.8. Meetings of a community improvement committee or association?

Cp9. Meetings of an association of professionals, merchants, manufacturers or farmers?

Cp13. Meetings of a political party or political organization?

$\mathrm{Cp} 21$. Meetings of sports or recreation groups?

Participation in community organizations ranges from 0 to 100 , with a mean of 18 . The empirical, aggregate-level range runs from 11.40 in Argentina to 25.42 in Bolivia.

\footnotetext{
${ }^{2}$ One of the big advantages of LAPOP surveys to understand public opinion trends in Latin America is their broad comparability. The same questions are asked to respondents in different countries across Latin America, which facilitates a comparative analysis.
} 


\section{INDEPENDENT VARIABLES}

The main individual-level predictor in the analysis is crime victimization. Victims are persons who, individually or collectively, have suffered harm, including physical or mental injury, emotional suffering, economic loss or substantial impairment of their fundamental rights, through acts or omissions that are in violation of criminal laws operative within Member States, including those laws proscribing criminal abuse of power (UNDP, 2010). To tap on crime victimization, responses to two questions are combined. The first question assesses individual victimization: "Now, changing the subject, have you been a victim of any type of crime in the past 12 months? That is, have you been a victim of robbery, burglary, assault, fraud, blackmail, extortion, violent threats or any other type of crime in the past 12 months?" And the second, asks for household victimization: "Has any other person living in your household been a victim of any type of crime in the past 12 months?" Values: 0, 1; victim of crime (either the respondent or someone in household) $=1,0$ otherwise. In this sample, the average crime victimization rate is 21 percent, with a maximum rate of 48 percent in the Ecuador survey.

The goal of this article is to assess whether victims of crime participate in community associations more than non-victims, and to determine how their community participation varies depending on their country level of corruption. Therefore, the main country-level independent variable is corruption. To measure corruption, I rely on Transparency International's Corruption Perceptions Index, which gauges the perceived level of public-sector corruption. The CPI is a composite measure, consisting of 13 items from 11 independent institutions, that gathers perceptions of corruption among country experts and business leaders. 3 The index ranges from 0 to 10 , with lower scores indicating lower levels of corruption. For a more straightforward interpretation, the scale was reversed so that higher scores on the CPI point to higher levels of corruption in government. The index provides measures for all Latin American countries except for Belize. As shown in Figure 1, in 2011, the most corrupt Latin American country was Venezuela with a score of 81 , and the cleanest was Chile with a score of 28.

\footnotetext{
3 The Corruption Perceptions Index has been widely used in scholarly work about corruption (Anderson and Tverdova, 2003; Hakhverdian and Mayne, 2012).
} 
The models control for a set of individual-level covariates that are likely to determine both crime victimization and participation in community associations. I include a standard battery of socio-economic status indicators (age, education, gender, self-reported income, urban/rural environment) based on previous findings that these might determine the chances of being victimized and the likelihood of community participation. Also, I include a control for the perceived presence of gangs, which is linked to a higher probability of crime victimization and lower levels of social capital (CORBACHO, PHILIPP, AND RUIZ-VEGA, 2015). This is gathered through a LAPOP survey question that asks: AOJ17. To what extent do you think your neighborhood is affected by gangs? Table 1 presents basic summary statistics.

\section{METHODS}

To test the hypotheses about the effects of victimization on community participation, and the interaction effects of corruption on participation, I proceed as follows. First, in order to overcome the limitations of reverse causation, the study uses Propensity Score Matching (PSM). Like in the case of most social problems, a challenge in the estimation of these effects is reverse causation or endogeneity. First, crime victimization may have an effect on participation, but the reverse relationship could also hold; individuals with a more active associational life could offer more opportunities for crime victimization. Likewise, being a victim of crime may induce individuals to withdraw from social life, and also being socially isolated might put subjects under higher risks of victimization. PSM allows to compare victimized and non-victimized subjects who are similar in the factors leading to victimization, so that after matching, individuals are different only with respect to their victimization status. The idea underlying propensity score matching is to adjust multiple-case comparisons for their pretreatment observable differences. In this case, we need to single out individuals who are were otherwise similar in a series of observable characteristics that predict being a victim of crime, but with the exception that some of them will actually have been victims of crime, and others will not. The logit models include fixed effects for urban (vs. rural) locations, and controls for individual personal and socioeconomic characteristics, and perceptions of the presence of gangs. Once the model was estimated, we obtained the predicted probability of being victimized, the propensity scores for each individual in the survey. Then I estimate the average treatment effect on the treated (ATT) conditional on the propensity score, matching each victim with a non-victim with a similar 
propensity score using three conventional methods in the literature: nearest neighbor, kernel, and stratification matching.

Second, since individuals are nested within national contexts that vary in terms of corruption levels, an explicitly multilevel modeling strategy is in order. As a first step toward building multilevel models, I check whether and to what extent the dependent variable varies across the two levels of analysis: individuals and countries. I assess whether community participation varies across individual respondents and across countries. To do so, first I decompose the variance in community participation into individual-level variance and countrylevel variance by running what is called and empty model. The larger share of variation in the dependent variable, community particicipation, takes place across individuals; however, the variance across countries, which reaches as much as 22 percent, is not negligible. Second, the results of a one-way analysis of variance (ANOVA) revealed significant differences between countries $(\mathrm{F}(17,30766)=180.75, \mathrm{p}=0.000)$ implying that although individual-level factors have more variance to explain than country-level factors have strong explanatory power. Ignoring the multilevel nature of the data could create a number of statistical problems such as clustering and underestimation of standard errors, among others (RAUDENBUSH AND BRYK, 2002; SNIJDERS AND BOSKER, 1999).

In order to account for the nested structure of the data and the sources of variance at different levels of analysis, I specify fixed-effects multilevel models with two levels of analysis. Individual-level effects are estimated in the following equation:

$$
\begin{gathered}
{\text { Community } \text { Participation }_{\mathrm{ij}}}=\beta_{0 \mathrm{j}}+\beta_{1 \mathrm{j}} \text { Victimization }_{\mathrm{ij}}+\beta_{2 \mathrm{j}} \text { Gangs }+\beta_{3 \mathrm{j}} \text { Urban }_{i j} \\
+\beta_{4 \mathrm{j}} \text { Education }_{\mathrm{ij}}+\beta_{5 \mathrm{j}} \text { Age }_{\mathrm{ij}}+\beta_{6 \mathrm{j}} \text { Age }_{\mathrm{ij}}+\beta_{7 \mathrm{j}} \text { Gender }_{i j}+\varepsilon
\end{gathered}
$$

This equation models respondents' community participation as a result of a country mean $(\beta 0 \mathrm{j})$ and individual deviations from it caused by the independent variables as well as the individual-specific error.

In addition, the country means are modeled as a function of the relevant country-level variable to analyze the effect of differences in corruption:

$$
\beta_{1 \mathrm{j}}=\gamma_{00}+\gamma_{01} \text { Corruption }+u_{0 \mathrm{j}}
$$


This equation tests the expectation that the average level of participation in community organizations will be higher as country-levels of corruption increase.

Lastly, the main hypothesis is that the positive effect of individual-level crime victimization on community participation will be intensified by the extent of country-level corruption. To assess this effect, models include a cross-level interaction term between corruption and victimization. The following equation models the effect of crime victimization in each country $j$ on community participation political support as a function of corruption levels.

$$
\beta_{1 \mathrm{j}}=\gamma_{10}+\gamma_{11} \text { Corruption }_{j}+u_{1 \mathrm{j}}
$$

This equation models the hypothesis that the difference in community participation between victims and non-victims will increase with changes in corruption.

\section{RESULTS}

\subsection{VICTIMIZATION AND COMMUNITY PARTICIPATION}

Propensity score matching.

The first step to carry out the propensity score matching, is to estimate a logit regression model to predict the probability that a given individual will be a victim, which is the treatment variable of interest. As shown in Figure 2, all observations are on support, which means that for each individual that was criminally victimized, a similar observation in terms of their covariates can be found.

Table 2 describes the results of the logit model and shows that several variables are significantly associated with crime victimization. The presence of gangs and living in an urban setting, being male, and higher income and education are all positively and significantly associated with being a victim of crime.

To compute the average treatment effect of the treated (ATT), the three conventional methods were applied: nearest neighbor, kernel, and stratification matching. The results presented in Table 3 provide support for the hypothesis about the positive relationship between crime victimization and community participation. Survey respondents who have been victimized are more likely to participate in community organizations. These results are statistically significant.

\subsection{CORRUPTION, VICTIMIZATION, AND COMMUNITY PARTICIPATION}


The analyses have shown than victimization has a positive effect on participation in community organizations. Individuals who have been victimized participate at higher rates than individuals who have not experienced crime victimization. Let us turn to the conditional effect of victimization on community participation depending on the level of corruption. In order to explore this conditional effect, I estimate two separate models. The first ignores the potential interaction between corruption and crime victimization and measures the direct effects of victimization and corruption on community participation for the average respondent in the sample. The second model includes the interaction term described in the third equation presented in the previous section. This second model tests the main hypothesis of this article, that the positive effect of crime victimization on community participation is larger as the levels of corruption increase.

The results displayed in Table 4 show that, on average, crime victimization induces higher levels of participation in community organizations. Knowing that victimization encourages participation adds to the scholarly work on the effects of crime victimization on social capital. However, these overall effects, which are observed by examining variation across individuals, may obscure interesting and important differences across countries. In particular, I expect the positive effect of crime victimization on participation to be more pronounced in contexts of higher levels of corruption, where citizens cannot trust institutions and therefore resort to their communities for support. In the second model of Table 4, I add the interaction term between corruption and crime victimization. The results indicate that crime victimization has a significantly more positive effect on community participation in countries with higher levels of corruption. The deviance comparison tests provide further evidence that the cross-level interaction term significantly contributes to the explanation of community participation. Finally, it should be noted that the coefficients of most of the individual-level control variables have the expected sign and are statistically significant.

How much does corruption matter, and how sensitive are victims as opposed to nonvictims? To illustrate the variable effect of corruption, I graph the predicted level of participation in community organizations for victims and non-victims of crime, with all other variables in the models set to their means. Figure 3 shows that victims report higher levels of community participation than non-victims, and that in countries with the highest levels of corruption in the 
sample victims' participation compared to that of non-victims is even larger than in countries that are more transparent, or less corrupt. Both victims and non-victims tend to participate more as corruption levels increase. However, the positive effect of higher levels of corruption is substantially larger on victims. Thus, in countries with high levels of corruption, victims of crime participate in community organizations much more than in less corrupt countries.

The results strongly support the hypothesis that crime victimization induces higher levels of community participation, and that this effect is especially pronounced in countries with higher levels of corruption. However, as a robustness check, I conduct the analyses with a measure of impartiality in order to further assess the effects of contextual government characteristics on the relationship between crime victimization and participation in community associations. To do so, I explore the conditional effects of impartiality of public administration on the association between victimization and participation (ROTHSTEIN AND STOLLE, 2008). I do so by analyzing the direct and interaction effects of an impartiality index from the Quality of Government Dataset (TEORELL ET AL., 2016). The index measures to what extent government institutions exercise their power impartially. And the impartiality norm is defined as: "When implementing laws and policies, government officials shall not take into consideration anything about the citizen/case that is not beforehand stipulated in the policy or the law" (TEORELL ET AL., 2016: 294). If the hypothesis of the conditional effect of crime victimization on community participation were true, we should expect higher levels of impartiality of government to have a negative effect on the relationship between victimization and participation. In societies where public institutions provide services in an impartial way, victims of crime should be able to meet their needs support, access to justice, etcetera) through institutional channels. Table 5 presents the results from the fixed effects models with country-level variable impartiality of public administrations. These results, which are consistent with those from the previous models, lend support to the hypothesis proposed. Model 3, which assesses the direct effects of impartiality of public administrations on participation shows a negative and statistically significant relation between the former and participation in community associations. In turn model 4, which tests the moderating effect of government impartiality on the relationship between crime victimization and participation in community associations, shows that the interaction term between impartiality and participation is negative and statistically significant. Thus, we can conclude that in Latin 
America, victims of crime do participate more in community associations than non-victims, and that victims are more inclined to participate when government institutions are more corrupt and less impartial.

\section{CONCLUSIONS}

The existing research on the consequences of exposure to violence -criminal and politicalon social capital yields opposite findings. One strand of the literature emphasizes that victims are more prone to withdraw, and the other highlights the positive effect of victimization on social and political participation. This paper analyzes the conditions under which crime victimization encourages participation in community associations. This article argued that the choice to increase participation after victimization is shaped by the level of government corruption. Under high levels of corruption, where trust in political institutions and generalized trust are low, victims of crime are discouraged from seeking support from broad social institutions, and more inclined to participate in closed-knit associations within their communities. As levels of corruption decline, victims can search for support from broader social organizations and participation in community associations declines.

The paper tested this argument by analyzing the impact of the interaction between corruption and crime victimization on participation in community associations. The analysis was based on data from the 2012 AmericasBarometer (LAPOP) survey. The findings showed, first, that crime victimization is strongly and significantly related to participation in community organizations, and second, that the effect of victimization on participation is intensified by the level of corruption.

\section{REFERENCES}

ANDERSON, Christopher J.; TVERDOVA, Yuliya V. Corruption, Political Allegiances, and Attitudes Toward Government in Contemporary Democracies. American journal of political science, v. 47, n.1, p. 91-109, 2003.

BANERJEE, Ritwik. Corruption, norm violation and decay in social capital. Journal of public economics, v. 137, n. 1, p. 14-27, 2016.

BASTIAN, Brock; JETTEN, Jolanda; FERRIS, Laura J. Pain as social glue: Shared pain increases cooperation. Psychological Science, v. 25, n. 11, p. 2079-2085, 2014. 
BATESON, Regina. Crime victimization and political participation. American Political Science Review, v. 106, n. 3, p. 570-587, 2012.

BELLOWS, John; MIGUEL, Edward. War and institutions: New evidence from Sierra Leone. The American economic review, v. 96, n. 2, p. 394-399, 2006.

BELLOWS, John; MIGUEL, Edward. War and local collective action in Sierra Leone. Journal of Public Economics, v. 93, n. 11, p. 1144-1157, 2009.

BLATTMAN, Christopher. From violence to voting: War and political participation in Uganda. American Political Science Review, v. 103, n. 2, p. 231-247, 2009.

BOWLER, Shaun; KARP, Jeffrey A. Politicians, scandals, and trust in government. Political Behavior, v. 26, n. 3, p. 271-287, 2004.

BREHM, John; RAHN, Wendy. Individual-level evidence for the causes and consequences of social capital. American journal of political science, p. 999-1023, 1997.

COHEN, Mark A. The effect of crime on life satisfaction. The Journal of Legal Studies, v. 37, n. S2, p. S325-S353, 2008.

CORBACHO, Ana; PHILIPP, Julia; RUIZ-VEGA, Mauricio. Crime and erosion of trust: Evidence for Latin America. World Development, v. 70, p. 400-415, 2015.

CHANG, Eric CC; CHU, Yun-han. Corruption and trust: exceptionalism in Asian democracies?. The Journal of Politics, v. 68, n. 2, p. 259-271, 2006.

CHENG, Zhiming; SMYTH, Russell. Crime victimization, neighborhood safety and happiness in China. Economic Modelling, v. 51, p. 424-435, 2015.

DE LUCA, Giacomo; VERPOORTEN, Marijke. Civil war and political participation: evidence from Uganda. Economic Development and Cultural Change, v. 64, n. 1, p. 113-141, 2015.

DELLA PORTA, Donatella. Social capital, beliefs in government, and political corruption. Disaffected democracies: What's troubling the trilateral countries, p. 202-228, 2000.

DRAKULICH, Kevin M. Concerns for self or family? Sources of and responses to altruistic fear. Journal of interpersonal violence, v. 30, n. 7, p. 1168-1207, 2015.

DUGAN, Laura. The effect of criminal victimization on a household's moving decision. Criminology, v. 37, n. 4, p. 903-930, 1999.

GILligAN, Michael J.; PASQUALE, Benjamin J.; SAMII, Cyrus. Civil war and social cohesion: Lab- in- the- field evidence from Nepal. American Journal of Political Science, v. 58, n. 3, p. 604-619, 2014. 
GRAEFF, Peter; SVENDSEN, Gert Tinggaard. Trust and corruption: The influence of positive and negative social capital on the economic development in the European Union. Quality \& Quantity, p. 1-18, 2013.

HAKHVERDIAN, Armen; MAYNE, Quinton. Institutional trust, education, and corruption: A micro-macro interactive approach. The Journal of Politics, v. 74, n. 3, p. 739-750, 2012.

HERREROS, Francisco; CRIADO, Henar. The state and the development of social trust. International Political Science Review, v. 29, n. 1, p. 53-71, 2008.

HUGHES, Marion R.; GAINES, Jonathan S.; PRYOR, Douglas W. Staying away from school: Adolescents who miss school due to feeling unsafe. Youth Violence and Juvenile Justice, v. 13, n. 3, p. 270-290, 2015.

INOGUCHI, Takashi. Broadening the basis of social capital in Japan. 2002. Democracies in flux: the evolution of social capital in contemporary society, p. 359-392. Oxford: Oxford University Press, 2002.

JAYAWICKREME, Eranda; BLACKIE, Laura ER. Post- traumatic growth as positive personality change: Evidence, controversies and future directions. European Journal of Personality, v. 28, n. 4, p. 312-331, 2014.

JENNINGS, M. Kent; ANDERSEN, Ellen Ann. Support for confrontational tactics among AIDS activists: A study of intra-movement divisions. American Journal of Political Science, p. 311334, 1996.

JENNINGS, M. Kent. Political Responses to Pain and Loss Presidential Address, American Political Science Association, 1998. American Political Science Review, v. 93, n. 1, p. 1-13, 1999.

MIETHE, Terance D. Fear and withdrawal from urban life. The Annals of the American Academy of Political and Social Science, v. 539, n. 1, p. 14-27, 1995.

MILES, Matthew R. Turnout as Consent: How Fair Governance Encourages Voter Participation. Political Research Quarterly, v. 68, n. 2, p. 363-376, 2015.

OTO- PERALÍAS, Daniel. The Long- term Effects of Political Violence on Political Attitudes: Evidence from the Spanish Civil War. Kyklos, v. 68, n. 3, p. 412-442, 2015.

POWDTHAVEE, Nattavudh. Unhappiness and crime: evidence from South Africa. Economica, v. 72, n. 287, p. 531-547, 2005.

PUTNAM, Robert D. Bowling alone: The collapse and revival of American community. Simon and Schuster, 2001. 
RAUDENBUSH, Stephen W.; BRYK, Anthony S. Hierarchical linear models: Applications and data analysis methods. Sage, 2002.

RICHEY, Sean. The impact of corruption on social trust. American Politics Research, v. 38, n. 4, p. 676-690, 2010.

ROTHSTEIN, Bo; STOLLE, Dietlind. Social capital, impartiality and the welfare state: An institutional approach. In: Generating social capital. Palgrave Macmillan US, 2003. p. 191-209.

ROTHSTEIN, Bo; STOLLE, Dietlind. The state and social capital: An institutional theory of generalized trust. Comparative politics, v. 40, n. 4, p. 441-459, 2008.

ROTHSTEIN, Bo; USLANER, Eric M. All for all: Equality, corruption, and social trust. World politics, v. 58, n. 1, p. 41-72, 2005.

SELIGSON, Mitchell A. The impact of corruption on regime legitimacy: A comparative study of four Latin American countries. The journal of Politics, v. 64, n. 2, p. 408-433, 2002.

TOM, A. B.; BOSKER, Tom AB Snijders Roel J.; BOSKER, Roel J. Multilevel analysis: an introduction to basic and advanced multilevel modeling. Sage, 1999.

SOUTH, Scott J.; CROWDER, Kyle D. Escaping distressed neighborhoods: Individual, community, and metropolitan influences. American Journal of Sociology, v. 102, n. 4, p. 10401084, 1997.

STAUBLI, Silvia; KILLIAS, Martin; FREY, Bruno S. Happiness and victimization: an empirical study for Switzerland. European Journal of Criminology, v. 11, n. 1, p. 57-72, 2014.

STICKLEY, Andrew et al. Crime and subjective well-being in the countries of the former Soviet Union. BMC public health, v. 15, n. 1, p. 1010, 2015.

TAO, Ran et al. How does political trust affect social trust? An analysis of survey data from rural China using an instrumental variables approach. International Political Science Review, v. 35, n. 2, p. 237-253, 2014.

TEDESCHI, Richard G.; CALHOUN, Lawrence G. " Posttraumatic growth: Conceptual foundations and empirical evidence". Psychological inquiry, v. 15, n. 1, p. 1-18, 2004.

TEORELL, Jan et al. The Quality of Government Standard Dataset, version Jan16. University of Gothenburg: The Quality of Government Institute. 2016.

UNDP. Manual on Victimization Surveys. Geneva: UNDP, 2010.

UNODC. Global Study on Homicide. Trends, Context, Data. Vienna: UNODC, 2014. 
USLANER, Eric M. Corruption, inequality, and the rule of law: The bulging pocket makes the easy life. Cambridge University Press, 2008.

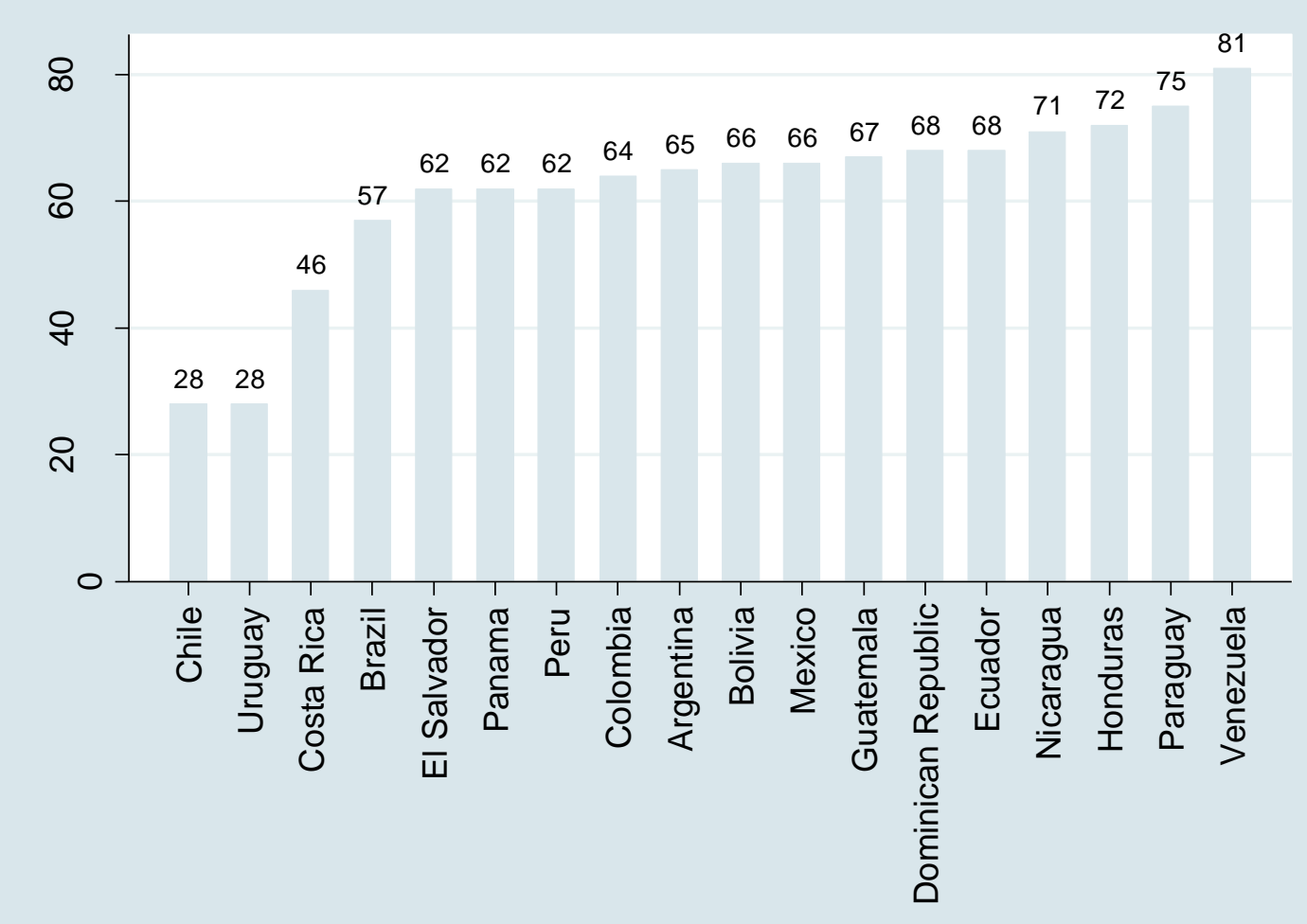

YOU, Jong- sung - Social trust:

Fairness matters more than homogenei ty. Politica

Psycholog

$y$, v. 33, n.

5 , p. $701-$

$721,2012$.

ANEXO

Figura 1 
Figure 1. Corruption Perceptions Index in Latin America 2011. Transparency International.

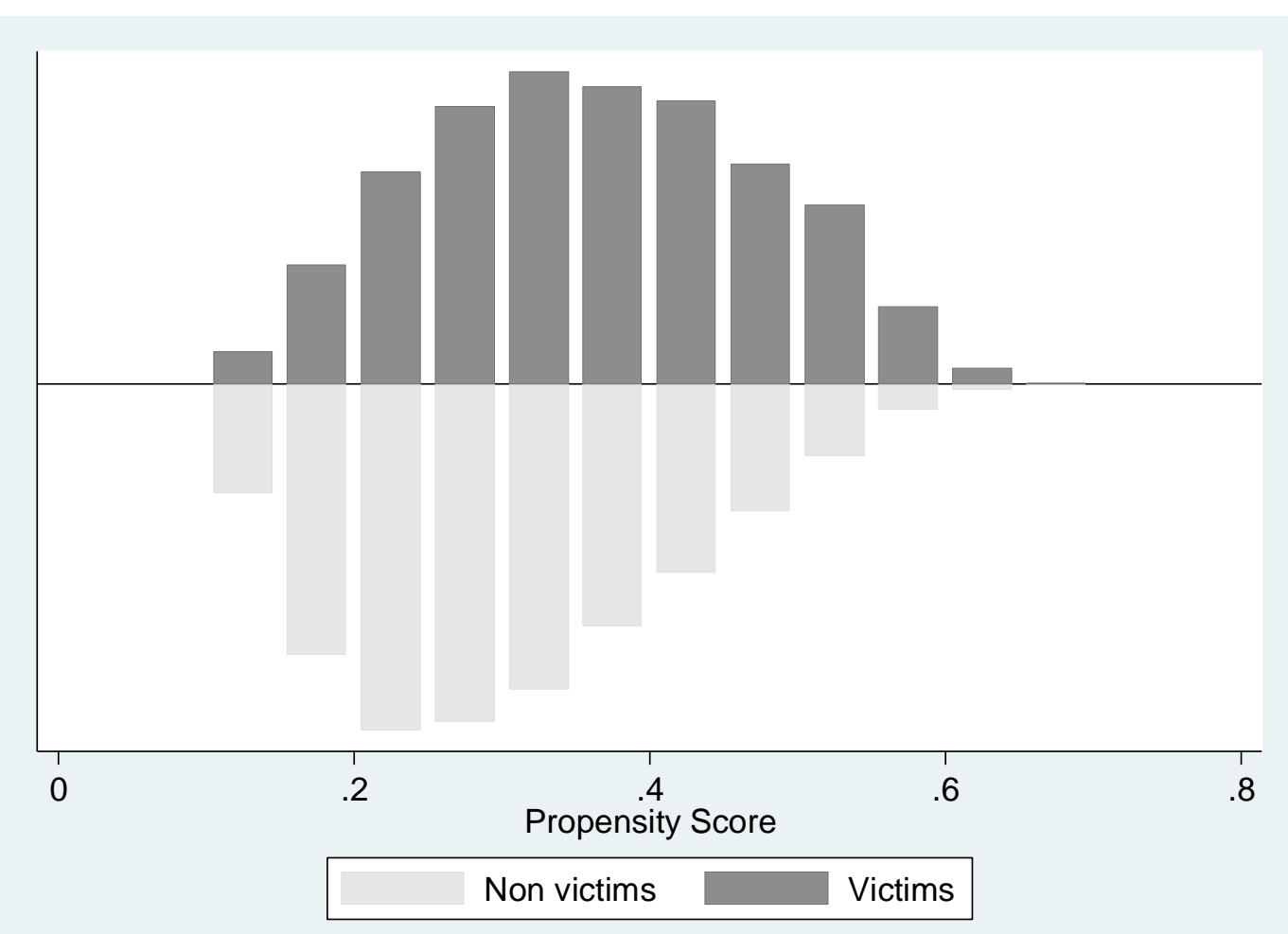

APÊNDICE S

Figura 2 
Figure 2. Common support of overlap region.

Figura 3

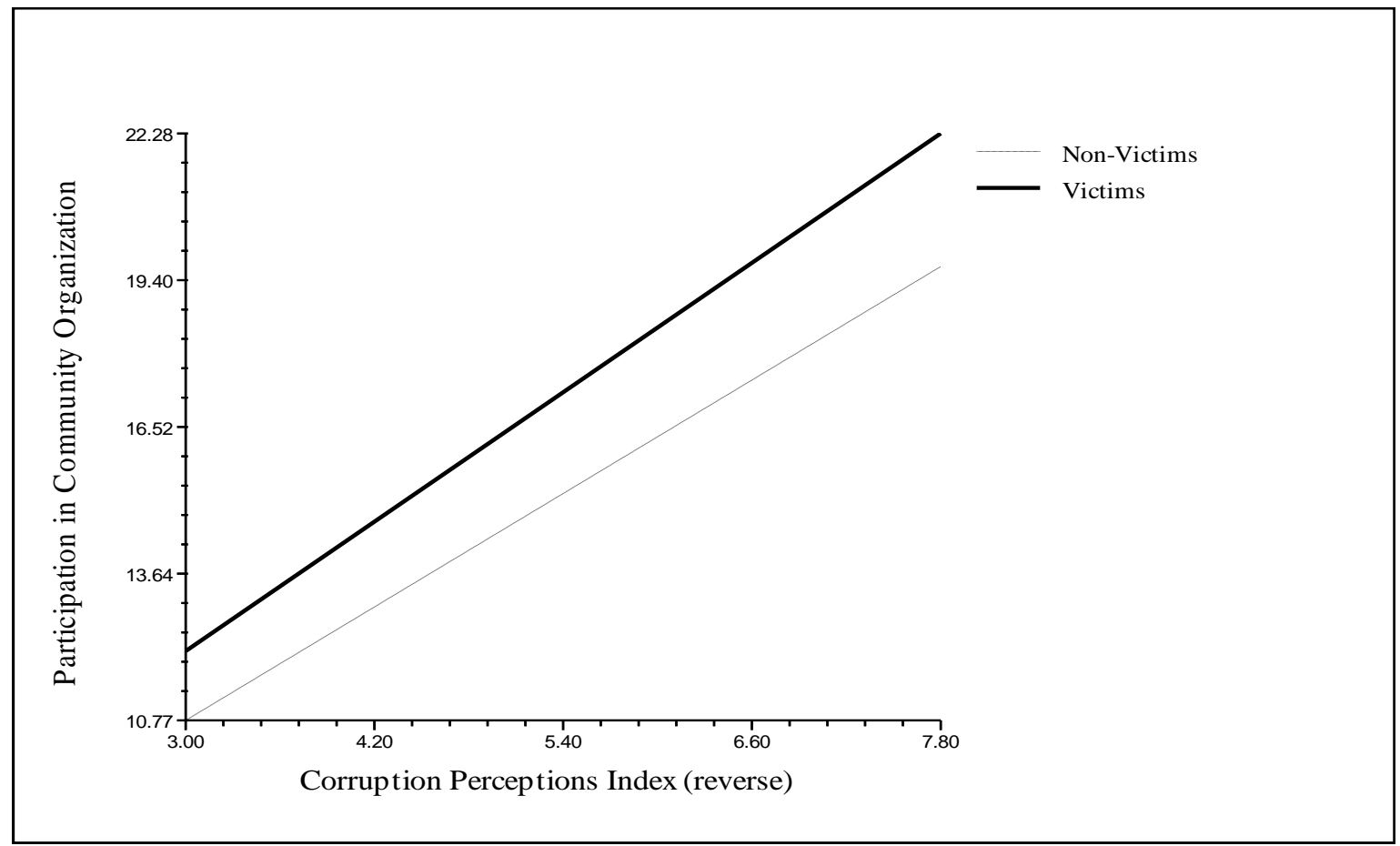

Figure 3. Effect of corruption on Community Participation in Victims and Non-Victims of Crime 


\section{Tabela 1}

\begin{tabular}{|c|c|c|c|c|c|c|c|c|}
\hline & & Community & Victims & Gangs & Male & Age & Education & Urban \\
\hline \multirow{3}{*}{ Argentina } & $\mathrm{N}$ & 1468 & 1459 & 1487 & 1512 & 1498 & 1507 & 1512 \\
\hline & Mean & 11.404 & 0.357 & 36.087 & 0.498 & 41.893 & 10.472 & 1.119 \\
\hline & S.D. & 12.140 & & 33.070 & & 17.110 & 3.757 & \\
\hline \multirow{3}{*}{ Bolivia } & $\mathrm{N}$ & 2860 & 2954 & 2969 & 3029 & 3029 & 3026 & 3029 \\
\hline & Mean & 25.417 & 0.411 & 40.762 & 0.497 & 37.442 & 9.829 & 1.370 \\
\hline & SD & 15.922 & & 33.199 & & 15.288 & 4.895 & \\
\hline \multirow{3}{*}{ Brazil } & $\mathrm{N}$ & 1452 & 1453 & 1480 & 1499 & 1497 & 1495 & 1499 \\
\hline & Mean & 14.491 & 0.265 & 44.411 & 0.496 & 37.836 & 8.984 & 0.878 \\
\hline & SD & 13.024 & & 34.391 & & 14.204 & 3.778 & \\
\hline \multirow{3}{*}{ Chile } & $\mathrm{N}$ & 1547 & 1535 & 1543 & 1571 & 1570 & 1562 & 1571 \\
\hline & Mean & 12.604 & 0.214 & 34.065 & 0.365 & 46.777 & 10.411 & 1.133 \\
\hline & SD & 11.962 & & 31.432 & & 16.988 & 4.134 & \\
\hline \multirow{3}{*}{ Colombia } & $\mathrm{N}$ & 1497 & 1490 & 1485 & 1512 & 1449 & 1445 & 1512 \\
\hline & Mean & 17.624 & 0.338 & 37.753 & 0.50 & 36.903 & 9.582 & 0.785 \\
\hline & SD & 13.418 & & 37.365 & & 14.698 & 4.341 & \\
\hline \multirow{3}{*}{ Costa Rica } & $\mathrm{N}$ & 1434 & 1477 & 1470 & 1498 & 1483 & 1485 & 1498 \\
\hline & Mean & 12.804 & 0.343 & 36.278 & 0.487 & 43.480 & 8.651 & 0.632 \\
\hline & SD & 12.516 & & 35.288 & & 17.711 & 4.391 & \\
\hline \multirow{3}{*}{$\begin{array}{l}\text { Dominican } \\
\text { Republic }\end{array}$} & $\mathrm{N}$ & 1482 & 1502 & 1488 & 1512 & 1511 & 1511 & 1512 \\
\hline & Mean & 24.476 & 0.311 & 48.877 & 0.499 & 39.451 & 9.448 & 0.646 \\
\hline & SD & 16.445 & & 37.502 & & 16.333 & 4.664 & \\
\hline \multirow{3}{*}{ Ecuador } & $\mathrm{N}$ & 1370 & 1475 & 1463 & 1500 & 1494 & 1481 & 1500 \\
\hline & Mean & 19.626 & 0.482 & 39.938 & 0.499 & 39.001 & 10.489 & 0.655 \\
\hline & SD & 15.028 & & 34.171 & & 14.607 & 4.267 & \\
\hline \multirow{3}{*}{ El Salvador } & $\mathrm{N}$ & 1473 & 1468 & 1464 & 1496 & 1458 & 1491 & 1497 \\
\hline & Mean & 20.068 & 0.288 & 37.816 & 0.501 & 40.299 & 7.477 & 0.645 \\
\hline & SD & 13.821 & & 35.851 & & 17.443 & 4.902 & \\
\hline \multirow{3}{*}{ Guatemala } & $\mathrm{N}$ & 1420 & 1495 & 1501 & 1509 & 1506 & 1504 & 1509 \\
\hline & Mean & 25.263 & 0.334 & 35.995 & 0.509 & 38.728 & 6.911 & 0.463 \\
\hline & SD & 16.653 & & 33.953 & & 14.813 & 4.711 & \\
\hline \multirow{3}{*}{ Honduras } & $\mathrm{N}$ & 1583 & 1651 & 1685 & 1728 & 1728 & 1706 & 1728 \\
\hline & Mean & 22.250 & 0.317 & 28.900 & 0.5 & 39.281 & 6.730 & 0.5 \\
\hline & SD & 17.811 & & 34.673 & & 16.374 & 4.627 & \\
\hline \multirow[b]{3}{*}{ Mexico } & $\mathrm{N}$ & 1530 & 1552 & 1540 & 1560 & 1547 & 1554 & 1560 \\
\hline & Mean & 16.018 & 0.336 & 39.953 & 0.490 & 40.050 & 8.759 & 0.753 \\
\hline & SD & 13.768 & & 32.188 & & 15.675 & 4.223 & \\
\hline
\end{tabular}




\begin{tabular}{|c|c|c|c|c|c|c|c|c|}
\hline & $\mathrm{N}$ & 1644 & 1679 & 1680 & 1686 & 1686 & 1686 & 1686 \\
\hline \multirow{2}{*}{ Nicaragua } & Mean & 21.702 & 0.250 & 30.236 & 0.5 & 39.052 & 6.824 & 0.594 \\
\hline & SD & 15.590 & & 34.180 & & 16.261 & 4.567 & \\
\hline \multirow{3}{*}{ Panama } & $N$ & 1527 & 1580 & 1562 & 1620 & 1620 & 1599 & 1620 \\
\hline & Mean & 12.376 & 0.101 & 42.165 & 0.5 & 38.844 & 10.465 & 0.659 \\
\hline & SD & 12.988 & & 34.705 & & 16.428 & 3.678 & \\
\hline \multirow{3}{*}{ Paraguay } & $N$ & 1486 & 1434 & 1488 & 1510 & 1503 & 1504 & 1510 \\
\hline & Mean & 23.189 & 0.261 & 31.785 & 0.510 & 36.654 & 9.248 & 0.566 \\
\hline & SD & 14.735 & & 33.962 & & 12.882 & 4.431 & \\
\hline \multirow{3}{*}{ Peru } & $\mathrm{N}$ & 1416 & 1450 & 1483 & 1500 & 1500 & 1499 & 1500 \\
\hline & Mean & 19.187 & 0.441 & 41.130 & 0.499 & 39.379 & 11.014 & 0.768 \\
\hline & SD & 13.854 & & 34.327 & & 15.685 & 3.956 & \\
\hline \multirow{3}{*}{ Uruguay } & $\mathrm{N}$ & 1466 & 1496 & 1480 & 1512 & 1508 & 1507 & 1512 \\
\hline & Mean & 11.741 & 0.340 & 36.303 & 0.498 & 45.612 & 9.591 & 0.920 \\
\hline & SD & 12.267 & & 34.994 & & 18.065 & 4.012 & \\
\hline \multirow{3}{*}{ Venezuela } & $\mathrm{N}$ & 1469 & 1471 & 1482 & 1500 & 1462 & 1483 & 1500 \\
\hline & Mean & 14.738 & 0.352 & 46.150 & 0.50 & 40.445 & 10.590 & 1.087 \\
\hline & SD & 14.793 & & 31.262 & & 14.134 & 3.831 & \\
\hline
\end{tabular}

\section{Tabela 2}

\begin{tabular}{|l|c|}
\hline Table 2. Logit estimates of the propensity of being victimized \\
\hline Presence of gangs & $.0117^{* * *}$ \\
& $(.0004)$ \\
\hline Urban resident & $.154 * * *$ \\
& $(.029)$ \\
\hline Male & $.058^{* *}$ \\
& $(.028)$ \\
\hline Age & -.003 \\
& $(.004)$ \\
\hline Age (squared) & -.002 \\
& $(.0005)$ \\
\hline Income & $.032 * * *$ \\
& $(.003)$ \\
\hline Education & $.047 * * *$ \\
& $(.003)$ \\
\hline Constant & -1.894 \\
& $(.108)$ \\
\hline Observations & 23695 \\
\hline Log likelihood & -14170.269 \\
\hline$* * * p<0.001, * * p<0.01, * p<0.05$ & \\
\hline
\end{tabular}




\section{Tabela 3}

\begin{tabular}{|l|l|l|}
\hline \multicolumn{3}{|l|}{ Table 3. Propensity score matching: average treatment effects on the treated (ATT) } \\
\hline Dependent Variable & Matching method & ATT \\
\hline Community participation & Nearest neighbor & $\begin{array}{l}3.294 * * * \\
(0.327)\end{array}$ \\
\hline & & $2.267 * *$ \\
& Kernel matching & $(1.182)$ \\
\hline & & $3.142 * * *$ \\
& Stratification matching & $(.234)$ \\
\hline$* * * p<0.001, * * p<0.01, * p<0.05$ & \\
\hline
\end{tabular}

\section{Tabela 4}

\begin{tabular}{|c|c|c|}
\hline & Model 1 & Model 2 \\
\hline \multicolumn{3}{|l|}{$\begin{array}{l}\text { Country-Level } \\
\text { Variable }\end{array}$} \\
\hline Corruption (CPI) & $\begin{array}{c}0.191 * * \\
(0.069)\end{array}$ & $\begin{array}{c}1.854 * * * \\
(0.431)\end{array}$ \\
\hline \multicolumn{3}{|l|}{$\begin{array}{l}\text { Individual-Level } \\
\text { Variables }\end{array}$} \\
\hline Crime Victimization & $\begin{array}{c}2.299 * * * * \\
(0.194)\end{array}$ & $\begin{array}{c}0.579 \\
(0.930)\end{array}$ \\
\hline $\begin{array}{l}\text { Corruption* } \\
\text { Victimization }\end{array}$ & & $\begin{array}{l}0.260 * \\
(0.137)\end{array}$ \\
\hline Presence of gangs & $\begin{array}{l}-0.004 \\
(0.002)\end{array}$ & $\begin{array}{l}-0.004 \\
(0.004)\end{array}$ \\
\hline Urban resident & $\begin{array}{c}-1.464 * * * \\
(0.203)\end{array}$ & $\begin{array}{l}-1.470 \\
(1.000)\end{array}$ \\
\hline Male & $\begin{array}{c}0.614 * * * \\
(0.175)\end{array}$ & $\begin{array}{c}0.615 \\
(0.498)\end{array}$ \\
\hline Age & $\begin{array}{l}0.650 * * * \\
(0.0003)\end{array}$ & $\begin{array}{c}0.651 * * * \\
(0.060)\end{array}$ \\
\hline Age (squared) & $\begin{array}{c}-0.006 * * * \\
(0.0003)\end{array}$ & $\begin{array}{l}-0.006 * * * \\
(0.00006)\end{array}$ \\
\hline Education & $\begin{array}{c}0.284 * * * \\
(0.021)\end{array}$ & $\begin{array}{c}0.284 * * * \\
(0.051)\end{array}$ \\
\hline Constant & $\begin{array}{c}-9.786 * * \\
(4.460) \\
\end{array}$ & $\begin{array}{l}-10.132 \\
(4.493) \\
\end{array}$ \\
\hline Deviance & 218526.373 & $218522.141^{*}$ \\
\hline $\mathrm{N}$ (Individuals) & 29,255 & 29,255 \\
\hline $\mathrm{N}$ (Countries) & 18 & 18 \\
\hline
\end{tabular}


Tabela 5

\begin{tabular}{|l|c|c|}
\hline Table 5. Impartiality, Victimization, and Community Participation in Latin America \\
\hline & Model 3 & Model 4 \\
\hline Country-Level & & \\
Variable & $-2.781^{* *}$ & $-2.630^{* * *}$ \\
\hline Impartiality & $(1.097)$ & $(1.049)$ \\
\hline Individual-Level & & \\
Variables & & $4.107 * * *$ \\
\hline Crime Victimization & $2.374^{* * *}$ & $(0778)$ \\
& $(0.205)$ & $-0.493^{* *}$ \\
\hline Impartiality* & & $(0.213)$ \\
Victimization & & $-0.007 * *$ \\
\hline Presence of gangs & $-0.007 * *$ & $(0.002)$ \\
& $(0.002)$ & $-1.578^{* * *}$ \\
\hline Urban resident & $-1.574^{* * *}$ & $(0.222)$ \\
\hline Male & $(0.222)$ & $0.539^{* *}$ \\
& $0.540^{* *}$ & $(0.188)$ \\
\hline
\end{tabular}




\begin{tabular}{|l|c|c|}
\hline Age & $0.640^{* * *}$ & $0.641 * * *$ \\
& $(0.030)$ & $(0.030)$ \\
\hline Age (squared) & $-0.006^{* * *}$ & $-0.006^{* * *}$ \\
& $(0.0003)$ & $(0.00003)$ \\
\hline Education & $0.266^{* * *}$ & $0.265^{* * *}$ \\
& $(0.023)$ & $(0.023)$ \\
\hline Constant & $12.325^{* *}$ & $11.774 * *$ \\
& $(3.938)$ & $(3.948)$ \\
\hline Deviance & 183087.236 & $183081.907 * *$ \\
\hline $\mathrm{N}$ (Individuals) & 24,397 & 15 \\
\hline $\mathrm{N}$ (Countries) & 15 & 24,397 \\
\hline$* * * \mathrm{p}<0.001, * * \mathrm{p}<0.01, * \mathrm{p}<0.05$. Two-tailed tests of statistical significance. \\
Standard Errors in parentheses
\end{tabular}

Recebido em 11/05/2017. Aceito em 24/06/2017. Publicado em 21/09/2017.

DOI: 10.11606/issn.1676-6288.prolam.2016.132150 